\title{
Scorpion diversity in two types of seasonally dry tropical forest in the semi-arid region of Northeastern Brazil
}

\author{
Rodrigo Felipe Rodrigues Carmo ${ }^{1}$, Heyde Polyana Amorim ${ }^{1}$ \& Simão Dias Vasconcelos ${ }^{1,2}$ \\ ${ }^{1}$ Department of Zoology, Federal University of Pernambuco - UFPE, \\ Av. Professor Moraes Rego, CEP 50670-420, Recife, PE, Brazil \\ ${ }^{2}$ Corresponding author: Simão Dias Vasconcelos, e-mail: simaovasconcelos@yahoo.com.br
}

CARMO, R.F.R., AMORIM, H.P. \& VASCONCELOS, S.D. Scorpion diversity in two types of seasonally dry tropical forest in the semi-arid region of Northeastern Brazil. Biota Neotrop. (13)2: http://www.biotaneotropica. org.br/v13n2/en/abstract?short-commnication+bn03113022013

\begin{abstract}
Knowledge on arthropod assemblages in the Brazilian semideciduous dry forest (caatinga) is scarce, despite the increasing exposure to degradation due to human activities such as logging and intensive agriculture. We performed a short-term survey on the diversity of scorpions in two types of caatinga (hipoxerophytic and hiperxerophytic) in Pernambuco State, Northeastern Brazil. A combination of active collection and pitfall traps was used to sample soil scorpions. Six species belonging to two families were registered: Bothriurus asper, Bothriurus rochai (Bothriuridae), Tityus stigmurus, Tityus pusillus, Rhopalurus rochai and Ananteris franckei (Buthidae). There was no significant difference in the richness and the abundance of scorpions in the two types of caatinga. Bothriurus asper was the most abundant species in both environments. Regarding constancy, all species were classified as accidental.
\end{abstract}

Keywords: Arachnida, caatinga, conservation, Pernambuco, Scorpiones.

CARMO, R.F.R., AMORIM, H.P. \& VASCONCELOS, S.D. Diversidade de escorpiões em dois tipos de floresta tropical sazonalmente seca na região semiárida do nordeste do Brasil. Biota Neotrop. 13(2): http://www. biotaneotropica.org.br/v13n2/pt/abstract?short-commnication+bn03113022013

Resumo: O conhecimento sobre assembleias de artrópodos na floresta seca semidecídua brasileira (caatinga) é escasso apesar de sua crescente exposição à degradação devido a atividades humanas como agricultura intensiva e desmatamento. Foi realizada uma pesquisa de curta duração sobre a diversidade de escorpiões em dois tipos de caatinga (hipoxerófila e hiperxerófila) no Estado de Pernambuco, Nordeste do Brasil. Uma combinação de coleta ativa e armadilhas de queda foi usada para amostrar os escorpiões de solo. Seis espécies pertencentes a duas famílias foram registradas: Bothriurus asper, Bothriurus rochai (Bothriuridae), Tityus stigmurus, Tityus pusillus, Rhopalurus rochai e Ananteris franckei (Buthidae). Não houve diferença significativa na riqueza e abundância de escorpiões nos dois tipos de caatinga. Bothriurus asper foi a espécie mais abundante em ambos os ambientes. Quanto à constância, todas as espécies foram classificadas como acidentais.

Palavras-chave: Arachnida, caatinga, conservação, Pernambuco, Scorpiones. 


\section{Introduction}

The seasonally dry tropical forest located in the semi-arid region of Brazil, known as caatinga, is the least studied of all Brazilian biomes. It covers an estimated area of $6-9 \times 10^{5} \mathrm{~km}^{2}$ and corresponds to $c a .10 \%$ of the Brazilian territory (Figure 1). It is characterized by semi-arid climate, high potential evapotranspiration throughout the year $\left(1,500-2,000 \mathrm{~mm}^{-1}\right)$, and low and erratic rainfall (Sampaio 1995). Droughts are frequent - in 2012 the region experienced the most severe drought in the last decades, which poses challenges to the local biota and also to human populations (Organização... 2013). The climate, geomorphology, and vegetation of the caating $a$ are very heterogeneous, which may respond for marked differences in local biological communities (Andrade-Lima 1981).

Biodiversity conservation in the caatinga is hindered by the fragile efforts to create a system of protected natural areas (it currently covers $0.87 \%$ of the caatinga) and by intensive economic activities that can degrade large portions of this ecosystem (Santos \& Tabarelli 2002). Protection of local biodiversity is further threatened by the scarcity on ecological data on native species, particularly invertebrates, so that the actual richness of terrestrial arthropod species is likely to be underestimated. Also, observations on the ecology and geographical distribution of cryptic species, such as scorpions, frequently lack empirical support. Considering that the composition of arachnid assemblages can be influenced by the degree of human activity and also by the size of forest fragments (Miyashita et al. 1998, Shochat et al. 2004), it is unclear how these features may affect scorpion diversity.

The Order Scorpiones comprises approximately 1,500 species distributed worldwide, of which approximately $50 \%$ have been registered in the Neotropical region (Porto et al. 2010). So far, 130 species have been described in Brazil, of which 22 species belonging to two families are believed to occur in the caating a biome (Porto et al. 2010).
In this context, we performed a short-term inventory on scorpion diversity in forest fragments in the caatinga. Specifically we aimed to: i) compare the diversity of species in forest fragments with different levels of aridness, vegetation cover and proximity to human settlements; and ii) infer about the presence of medically important scorpions and the conservation status of local species. We tested the hypothesis that the scorpion assemblage would differ in the two types of caatinga due to differences in biotic characteristics such as relative humidity, overall temperature and rainfall pattern.

\section{Material and Methods}

This study was performed in two areas in the State of Pernambuco, Northeastern Brazil (Figure 1) differentiated mostly by size, vegetation cover, rainfall pattern and land use, and separated from each other by approximately $275 \mathrm{~km}$. The fragment of hipoxerophytic caatinga (40 ha, $554 \mathrm{~m}$ of altitude) is located $c a .5 \mathrm{~km}$ from the municipality of Caruaru $\left(8^{\circ} 15^{\prime} \mathrm{S}\right.$; $35^{\circ} 58^{\prime} \mathrm{W}$, pop. 325,000$)$, where services and industries are the main economic activities. It is characterized by mean temperature of $22.5^{\circ} \mathrm{C}$, annual rainfall of $610 \mathrm{~mm}$, shallow and moderately drained soils. The diverse vegetation consists of a mixture of xeric and mesic species and includes shrubs, native and introduced trees and occasionally subsistence crops. Surrounding human activities include agriculture, livestock (cattle) and wood extraction. The degree of conservation and protection from human presence is moderate, as the neighboring area is inhabited. Severe droughts rarely last over a year due to the proximity of rainforest enclaves.

The fragment of hiperxerophytic caatinga ( 820 ha, altitude of $440 \mathrm{~m}$ ) was located $\mathrm{ca} .30 \mathrm{~km}$ from the municipality of Serra Talhada ( $7^{\circ} 57^{\prime} \mathrm{S}$ and $38^{\circ} 22^{\prime} \mathrm{W}$, pop. 80,000 ), whose economic activity is based on agriculture. It is characterized by mean temperature of $25.2{ }^{\circ} \mathrm{C}$ (easily reaching over $40{ }^{\circ} \mathrm{C}$ ) and annual rainfall of $430 \mathrm{~mm}$; soils are shallow with limited water retention. Vegetation is composed of xeric shrub species, with the predominance of Cactaceae
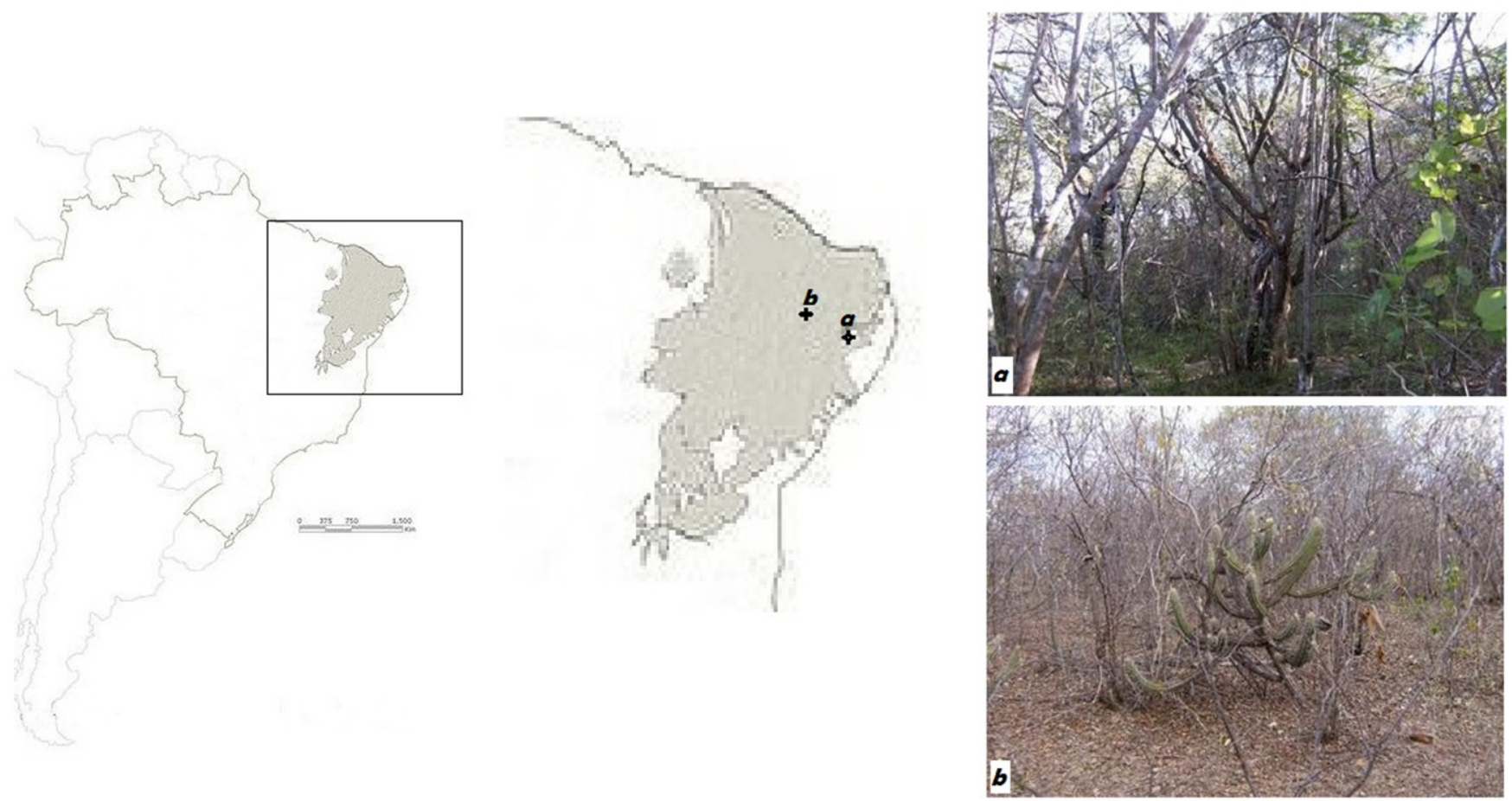

Figure 1. Location of the caatinga, Northeastern Brazil, with emphasis on the sampling sites: (a) hipoxerophytic caatinga and (b) hiperxerophytic caatinga. 
and sparsely distributed trees (e.g., Fabaceae, Anacardiaceae). Surrounding activities include livestock (goats, pigs). The degree of conservation and protection from human presence is high, as its owner uses the property for ecological restoration and environmental education projects. Droughts are cyclic and last 3-7 years.

Sampling was performed in December 2009 (dry season) and in April 2010 (rainy season). Two collecting methods were used: active collection and pitfall traps. For logistical reasons, active collection was performed during the day, by carefully searching on microhabitats such as under logs, stones, crevices on the soil, and others. Each sample consisted of a 30 minutes collection performed in areas separated from one another by at least $500 \mathrm{~m}$. A total of 16 samples were performed in each area, on different days. Pitfall traps consisted of $500 \mathrm{~mL}$ plastic cups buried at soil level, containing $200 \mathrm{~mL}$ of $70 \%$ alcohol. Traps were displayed in a $7 \times 7$ arrangement, with each trap separated equidistantly from one another by $10 \mathrm{~m}$. Each $7 \times 7$ grid corresponded to one sample. Pitfall traps were left in the field for 216 hours, and were emptied at every 48 hours, with replacement of alcohol. Three independent areas (replicates) separated from one another by at least $500 \mathrm{~m}$ were chosen in each forest type and were sampled by both methods in each season. Scorpions were stored in glass vials containing $70 \%$ alcohol and identified using the taxonomical keys of Lourenço (2002) and Souza et al. (2009).

For each scorpion species the abundance, dominance and constancy were estimated. Constancy was calculated as follows: $\mathrm{C}=(\mathrm{p} \times 100) / \mathrm{N}$, where $\mathrm{C}=$ constancy in $\%$ for each species; $\mathrm{p}=$ number of samples in which the species is present; $\mathrm{N}=$ total number of samples. Species were classified as constant (when present in $>50 \%$ of samples), accessory (present in $25 \%$ to $50 \%$ ) or rare $(<25 \%$ of samples). Dominance was calculated following Palissa et al. (1979) as $\mathrm{D} \%=(\mathrm{i} / \mathrm{t}) \mathrm{X} 100$, where: $i=$ abundance of species A and $t=$ total abundance. In this case, species were classified as eudominant (when dominance was higher than $10 \%$ ), dominant $(5 \%<\mathrm{D} \leq 10 \%$ ), subdominant $(2 \%<\mathrm{D} \leq 5 \%)$, recessive $(1 \%<\mathrm{D} \leq 2 \%)$ or rare $(\mathrm{D}<$ $1 \%)$. Shannon-Wiener's diversity index was calculated for each type of caatinga. Differences in the abundance between the two fragments and between dry and rainy seasons were calculated using a Chi-square test, with 5\% significance level.

\section{Results and Discussion}

Six species belonging to two families were registered throughout the trial: Bothriurus asper Pocock, 1893, Bothriurus rochai MelloLeitão, 1932 (Bothriuridae), Ananteris franckei Lourenço, 1982, Rhopalurus rochai Borelli, 1910, Tityus pusillus Pocock, 1893 and Tityus stigmurus (Thorell, 1876) (Buthidae). Because of the low abundance registered throughout the experiment, collections from dry and rainy season are shown together (Table 1). Low abundances have been a common feature of scorpion populations in Brazil when pitfall traps were the only capture method used. For example, in a 24 month study performed in a caatinga fragment, Araújo et al. (2010) recorded only 104 individuals of four species, all of which are reported here. Also, Dias et al. (2006) reported only 72 specimens belonging to four species in an urban rainforest fragment in Northeastern Brazil.

The richness varied little between the hiperxerophytic and the hipoxerophytic caatinga (4 and 6 species, respectively). Overall, $B$. asper was the most abundant species reaching $45.0 \%$ of individuals (Table 1). Seasonal scorpion abundance varied differently in the two xeric fragments: while no difference in the number of adults was observed between the dry and the rainy season in the hipoxerophytic caatinga $\left(\chi^{2}=2.81\right.$, d.f. $\left.=1 ; \mathrm{P}>0.05\right)$, scorpion abundance was higher in the rainy season in the hiperxerophytic caatinga $\left(\mathrm{c}^{2}=29.33\right.$ d.f. $=1 ; \mathrm{P}>0.05$ ). In the highly unpredictable weather conditions of the hiperxerophytic caatinga, rapid growth of vegetation following rainfall is associated with an increase in the abundance of insects (Araújo et al. 2010, Vasconcellos et al. 2010), which are the main component in the diet of scorpions.

Overall abundance was higher in the hipoxerophytic caatinga $\left(\mathrm{c}^{2}=4.41 ; \mathrm{P}<0.05\right)$, which is due to higher number of individuals of the species B. rochai and $R$. rochai collected in that biome. All species from both hipoxerophytic and hiperxerophytic caatinga were classified as accidental. This explained by the fact that most pitfall traps contained no individuals. Regarding dominance, Bothriurus asper was eudominant in both fragments. The low numbers of captured individuals may result from the lack of nocturnal collection or from biological and ecological features of the taxa, such as low fecundity and the cryptic habit of many species (Polis 1990). Also, several species seem to exhibit a spatially-limited foraging behavior that limits their capture in pitfall traps. Diversity indices were low to moderate and varied little between the two types of caatinga $\left(\mathrm{H}^{\prime}=2.12\right.$ for the hipoxerophytic and $\mathrm{H}^{\prime}=1.63$ for the hiperxerophytic caatinga. No marked differences were observed between the two fragments, although T. stigmurus was found only in the hipoxerophytic fragment.

Of the six species registered, Tityus stigmurus is the only one involved in lethal accidents in Pernambuco (Brasil 2009). This species is known to occur in several biomes in the Northeastern region (Porto et al. 2012). The remaining species have not yet been involved in serious accidents to human populations, although recently, T. pusillus was registered causing envenomation symptoms in Northeastern Brazil (Albuquerque et al. 2009). Also, reports of stings by $R$. rochai have been documented by local farmers in the caatinga (personal observation).

The number of accidents involving scorpions has risen $110 \%$ in six years in Northeastern Brazil, where $46.5 \%$ of all scorpionism cases in the country were registered (Brasil 2011). The medical

Table 1. Diversity, abundance (N), constancy (C) and dominance (D) of scorpions in two types of forest fragments in the Brazilian caatinga . RF $=$ relative frequency.

\begin{tabular}{|c|c|c|c|c|c|c|c|c|}
\hline \multirow{2}{*}{ Species } & \multicolumn{3}{|c|}{ Hipoxerophytic } & \multicolumn{3}{|c|}{ Hiperxerophytic } & \multirow{2}{*}{ Total } & \multirow{2}{*}{ RF (\%) } \\
\hline & $\mathbf{N}$ & $\mathrm{C}$ & $\mathbf{D}$ & $\mathbf{N}$ & $\mathrm{C}$ & D & & \\
\hline Ananteris franckei & 4 & Accidental & Dominant & 1 & Accidental & Recessive & 5 & 4.6 \\
\hline Bothriurus asper & 21 & Accidental & Eudominant & 28 & Accidental & Eudominant & 49 & 45.0 \\
\hline Bothriurus rochai & 4 & Accidental & Dominant & 15 & Accidental & Eudominant & 19 & 17.4 \\
\hline Rhopalurus rochai & 4 & Accidental & Dominant & 22 & Accidental & Eudominant & 26 & 23.9 \\
\hline Tityus pusillus & 2 & Accidental & Subdominant & 0 & - & - & 2 & 1.8 \\
\hline Tityus stigmurus & 8 & Accidental & Eudominant & 0 & - & - & 8 & 7.3 \\
\hline Total & 43 & & & 66 & & & 109 & 100 \\
\hline RF (\%) & 39.4 & & & 60.6 & & & 100 & \\
\hline
\end{tabular}


Scorpions from the Caatinga

Table 2. Scorpion species collected in the caatinga, related to their medical importance, conservation status and previous record on their environmental distribution. $\mathrm{UZ}=$ urban zone, $\mathrm{CA}=$ caatinga, $\mathrm{CE}=$ cerrado, $\mathrm{RF}=$ rainforest, $\mathrm{AM}=$ Amazon forest. $\mathrm{AG}=$ agro-ecosystems, $\mathrm{OI}=\mathrm{Oceanic}$ Island.

\begin{tabular}{|c|c|c|c|}
\hline Species & $\begin{array}{c}\text { Medical } \\
\text { Importance }\end{array}$ & $\begin{array}{c}\text { Conservation and/or } \\
\text { Invasive Status } \\
\end{array}$ & $\begin{array}{l}\text { Environmental } \\
\text { Distribution }\end{array}$ \\
\hline Ananteris franckei & Low & Not endangered, despite low populations in the field & $\mathrm{CA}, \mathrm{RF}$ \\
\hline Bothriurus asper & Low & Not endangered, usually dominant in xeric environments & $\mathrm{CA}, \mathrm{CE}, \mathrm{RF}, \mathrm{AG}$ \\
\hline Bothriurus rochai & Low & Not endangered & CA, CE, RF, UZ \\
\hline Rhopalurus rochai & Low & $\begin{array}{l}\text { Not endangered; species with some degree of environmental } \\
\text { plasticity }\end{array}$ & CA, CE, RF, UZ AG \\
\hline Tityus pusillus & Moderate & Not endangered & $\mathrm{CA}, \mathrm{RF}, \mathrm{UZ}$ \\
\hline Tityus stigmurus & High & $\begin{array}{l}\text { Not endangered; species with increasing geographical range, } \\
\text { in close contact with human populations }\end{array}$ & $\mathrm{CA}, \mathrm{CE}, \mathrm{RF}, \mathrm{UZ}, \mathrm{OI}$ \\
\hline
\end{tabular}

Sources: Lourenço (2002), Dias et al. (2006), Albuquerque et al. (2009), Brasil (2009) and Araújo et al. (2010).

relevance of scorpions in the caatinga is heightened considering that local population is mostly involved in agricultural activities, usually performed without protection such as gloves and boots. Recent studies suggest that the frequency of accidents may be higher than what it is compiled in medical records, due to sub-notification. For instance, almost $80 \%$ of farmers based in Tacaratu, a municipality located in the hiperxerophytic caatinga, claim to have been stung by scorpions, despite the low notification in the surrounding hospitals (Lima \& Vasconcelos 2006). The low toxicity of the venom of local species justifies the scarcity of hospital registers. However, the use of inadequate treatment based on popular knowledge and religious beliefs - which include healing rituals and the use of herb extracts - are popular in the caatinga and may produce undesirable side effects (Lima \& Vasconcelos 2006).

So far, no scorpion species has been included in the Brazilian National Red List for conservation (Table 2). However, that does not exclude longer-term risks to the species, as alterations in the natural landscape include roads, city development and replacement of native vegetation with agricultural crops, among others. Although the criteria for listing a given species as endangered (including population reduction, limited geographical range, among others) are mostly applied for vertebrates, Cardoso et al. (2010) claim that several taxa, such as arachnids, are likely to be excluded from conservation priorities due to peculiarities of their populations and the limited ecological data. These shortfalls include limited knowledge on the distribution, population changes in space and time and on the specie's sensitivity to habitat changes (Cardoso et al. 2010).

While it is early to infer about pressures for population reduction of the species registered here, Porto et al. (2010) performed a comprehensive study on scorpion diversity in the neighbor state of Bahia and concluded that three species, Tityus kuryi, Rhopalurus lacrau and Troglorhopalurus translucidus should be included in the "vulnerable" category, given their endemism, restricted distribution, and exposure to human presence. On the other hand, some opportunistic species could even be benefitted by a moderate degree of anthropogenic actions. For example, Tityus stigmurus seems to be expanding its geographical distribution; besides being recorded in urban zones, rainforest, cerrado and caatinga, it has been found in oceanic islands in Brazil, a fact that poses interesting questions on human mediated dispersal of medically important species (Freitas \& Vasconcelos 2008). T. stigmurus has been recorded with increasing frequency in urban environments in Northeastern Brazil and caused 42 deaths in Pernambuco state in the 2000-2010 period (Brasil 2011).

Lourenço (2002) argues that the diversity of scorpions in Brazil is relatively poor. So far, only 13 species have been registered in Pernambuco State: Ananteris franckei, A. mauryi, Bothriurus asper,
B. rochai, Isometrus maculatus, Physoctonus debili, Rhopalurus agamemnon, $R$. rochai, Tityus anneae, T. brazilae, T. neglectus, T. pusillus and T. stigmurus (Albuquerque et al., 2009). The diversity of scorpions recorded here is considered to be high given the fact that the survey was carried out in one of the driest areas of the caatinga biome, for a short period. It is possible that unknown species are described if more exhaustive field collections are accomplished, as evidenced by the recent description of Tityus alba in Northeastern Brazil (Candido et al. 2005).

The dearth of ecological and behavioral studies in the caatinga and the peculiarities of this biome raise interesting questions regarding the survival and dispersal in long periods of drought. Results presented here confirm the strong association of scorpion species to xeric environments and suggest that, so far, the composition and structure of scorpion assemblages does not vary markedly in conserved fragments of different phytophysiognomies. It is early to affirm that local species are experiencing a major risk of extinction, but given the rate of human mediated changes to which several areas of the caatinga have been recently exposed, endemic species should be the priority target for long- term ecological and behavioral studies.

\section{Acknowledgements}

We thank CNPq (Ministry of Science and Technology, Brazil) for the scholarship to the first author, Mr. Homembom Magalhaes for access to the experimental area, and Joao Aleixo, Rivaneide Matias and Renata Akemi for logistical support. The corresponding author has a productivity grant from $\mathrm{CNPq}$.

\section{References}

ALBUQUERQUE, C.M.R., PORTO, T.J., AMORIM, M.L. \& SANTANA NETO, P.L. 2009. Escorpionismo por Tityus pusillus Pocock, 1893 (Scorpiones; Buthidae) no Estado de Pernambuco. Rev. Soc. Bras. Med. Trop. 42:1-3. http://dx.doi.org/10.1590/S0037-86822009000200023

ANDRADE-LIMA, D. 1981. The Caatingas Dominium. Rev. Bras. Bot. 4:149-163.

ARAÚJO, C.S., CANDIDO, D.M., ARAÚJO, H.F.P., DIAS, S.C. \& VASCONCELLOS, A. 2010. Seasonal variations in scorpion activities (Arachnida: Scorpiones) in an area of Caatinga vegetation in Northeastern Brazil. Zoologia 27:372-376. http://dx.doi.org/10.1590/S198446702010000300008

BRASIL. Ministério da Saúde. Secretaria de Vigilância em Saúde. Epidemiológica. 2009. Manual de controle de escorpiões. Brasília.

BRASIL. Ministério da Saúde. Secretaria de Vigilância em Saúde. 2011. Sistema de Informação de Agravos de Notificação. http://portalsaude.saude.gov. br/portalsaude/arquivos/obitos_escorpioes_br_gd_reg_2000_2011.pdf (último acesso em 29/12/2012). 
CANDIDO, D.M., LUCAS, S., SOUZA, C.A.R., DIAZ, D. \& LIRA-DASILVA, R.M. 2005. Uma nova espécie de Tityus C.L. Koch, 1836 (Scorpiones, Buthidae) do estado da Bahia, Brasil. Biota Neotr. 5:193-200. http://dx.doi.org/10.1590/S1676-06032005000200018

CARDOSO, P., ERWIN, T.L., BORGES, P.A.V. \& NEW, T.R. 2011. The seven impediments in invertebrate conservation and how to overcome them. Biol. Cons. 144:2647-2655. http://dx.doi.org/10.1016/j. biocon.2011.07.024

DIAS, S.C., CANDIDO, D.M. \& BRESCOVIT, A.D. 2006. Scorpions from Mata do Buraquinho, João Pessoa, Paraíba, Brazil, with ecological notes on a population of Ananteris mauryi Lourenço (Scorpiones, Buthidae). Revta. Bras. Zool. 23:707-710. http://dx.doi.org/10.1590/ S0101-81752006000300014

FREITAS, G.C.C. \& VASCONCELOS, S.D. 2008. Scorpion fauna of the island of Fernando de Noronha, Brazil: first record of Tityus stigmurus (Thorell, 1877) (Arachnida, Buthidae). Biota Neotr. 8:235-237.

LIMA, K.E. \& VASCONCELOS, S.D. 2006. Acidentes com animais peçonhentos: um estudo de caso com agricultores de Tacaratu, sertão de Pernambuco. Sitient. Ciên. Biol. 6:138-144.

LOURENÇO, W.R. 2002. Scorpions of Brazil. Les Éditions de I'If, Paris.

MIYASHITA, T., SHINKAI, A. \& CHIDA, T. 1998. The effect of forest fragmentation on web spider communities in urban areas. Biol. Cons. 86:357-364. http://dx.doi.org/10.1016/S0006-3207(98)00025-1

ORGANIZAÇÃO DAS NAÇÕES UNIDAS - ONU. 2013. Pior Seca dos ultimos 50 anos no nordeste brasileiro confirma estatística da ONU sobre escassez. http://www.onu.org.br/pior-seca-dos-ultimos-50-anos-nonordeste-brasileiro-confirma-estatisticas-da-onu-sobre-escassez/ (último acesso em 03/05/2013).
PALISSA, A.E., WIEDENROTH, M. \& KLIMT, K. 1979. Anleitung zum ökologischen Geländepraktikum. Wissenschaftliches Zentrum der Pädagogischen Hochschule Potsdam, Potsdam, 186p.

POLIS, G.A. 1990. The Biology of Scorpions. Stanford University Press, Stanford.

PORTO, T.J., BRAZIL, T.K. \& LIRA-DA-SILVA, R.M. 2010. Scorpions, state of Bahia, Northeastern Brazil. CheckList. 6:292-297.

SAMPAIO, E.V.S.B. 1995. Overview of the Brazilian caatinga. In Seasonally Dry Tropical Forests (S.H. Bullock, H.E. Mooney \& E. Medina, eds.). Cambridge University Press, Cambridge. http://dx.doi.org/10.1017/ CBO9780511753398.003

SANTOS, A.M. \& TABARELLI, M. 2002. Distance from roads and cities as a predictor of habitat loss and fragmentation in the caatinga vegetation of Brazil. Braz. J. Biol. 62:897-905. PMid:12659042. http://dx.doi. org/10.1590/S1519-69842002000500020

SHOCHAT, E., STEFANOV, W.L. \& WHITEHOUSE, M.E.A. 2004. Urbanization and spider diversity: Influences of human modification of habitat structure and productivity. Ecol. Appl. 14:268-280. http://dx.doi. org/10.1890/02-5341

SOUZA, C.A.R., CANDIDO, D.M., LUCAS, S.M. \& BRESCOVIT, A.D. 2009. On the Tityus stigmurus complex (Scorpiones, Buthidae). Zootaxa 5:1-38.

VASCONCELLOS, A., ANDREAZZE, R., ALMEIDA, A.M., ARAUJO, H.F.P., OLIVEIRA, E.S. \& OLIVEIRA, U. 2010. Seasonality of insects in the semi-arid Caatinga of northeastern Brazil. Rev. Bras. Entomol. 54:471-476. http://dx.doi.org/10.1590/S008556262010000300019 